\title{
PENGARUH PENGGUNAAN LAYANAN APLIKASI DIGITAL GOOGLE PLAY DALAM SMARTPHONE TERHADAP PEMENUHAN KEBUTUHAN INFORMASI MAHASIWA
}

\section{EFFECT OF THE USE OF DIGITAL SERVICE APPLICATION ON GOOGLE PLAY SMARTPHONE IN MEETING THE INFORMATION NEEDS STUDENTS}

\author{
Rijallahudin'1a, IA Ratnamulyani², AA Kusumadinata ${ }^{3 a}$ \\ 1)Alumni Ps. Ilmu Komunikasi, Fakultas Ilmu Sosial dan Ilmu Politik, Universitas Djuanda Bogor. \\ 2)Dosen Pembimbing I Program Studi Komunikasi, Fakultas Ilmu Sosial dan Ilmu Politik, 3)Dosen \\ Pembimbing II Program Studi Komunikasi Universitas Djuanda Bogor, Jl. Tol No. 1 Kotak Pos 35 Bogor \\ 16720 \\ a Korespondensi E-mail :1 Rijallahudin@Unida.ac.id, alialamsyahkusumadinata@gmail.com
}

(Ditelaah: 10-08-2016; Disetujui: 06-09-2016)

\begin{abstract}
The development of communication technology has enable people to meet the information needs, one of them with a digital application service utilization google play in the smartphone. This study aimed to: (1) To find out how services digital content google play used by students Fisip Unida (2) to determine the faktor any that affect students in using the service apliaksi google play, and (3) to determine whether there was a relationship between the use google play digital application services to meet the needs of information. This study was designed using descriptive methods. The study population was FISIP University Djuanda Bogor, the sample was set at 81mahasiswa with simple random sampling techniques and data analysis performed using the Spearman rank correlation test. The results showed that (1) the development of communication technology utilized by students with the use of a digital application service google play as a medium to add information and entertainment. (2) faktors that affect the use of digital application service Google Play is the need affective, cognitive Supplies, Supplies imagenation, Needs integrative personal and social needs, and (3) there was a real relationship between to use google play with the fulfillment of information needs.
\end{abstract}

Keywords: development of communication technology, google play, information.

\begin{abstract}
ABSTRAK
Perkembangan teknologi komunikasi telah memudahkan manusia dalam memenuhi kebutuhan informasi, salah satunya dengan pemanfaatan layanan aplikasi digital google play dalam smartphone. Penelitian ini bertujuan: (1) Untuk mengetahui bagaimana layanan konten digital google play yang digunakan oleh mahasiswa (2) untuk mengetahui faktor apa saja yang memepengaruhi mahasiswa dalam menggunakan layanan apliaksi google play, serta (3) untuk mengetahui apakah terdapat hubungan antara penggunaan layanan aplikasi digital google play dengan pemenuhan kebutuhan informasi. Penelitian ini didesain menggunakan metode deskriptip. Populasi penelitian adalah responden kota Bogor, sampel ditetapkan sebanyak 81mahasiswa dengan teknik sampling acak sederhana dan analisis data dilakukan dengan menggunakan uji korelasi Rank Spearman. Hasil penelitian menunjukan bahwa (1) perkembangan teknologi komunikasi dimanfaatkan dengan baik oleh responden dengan penggunaan layanan aplikasi digital google play sebagai media untuk menambah informasi dan hiburan. (2) faktor yang memepengaruhi pengunaan layanan aplikasi digital Google Play adalah kebutuhan afektif, Kebutuhan kognitif, Kebutuhan berkhayal, Kebutuhan integratifvpersonal dan kebutuhan integratif sosial, serta (3) terdapat hubungan yang nyata antara pengunaan google play dengan pemenuhan kebutuhan informasi.
\end{abstract}

Kata Kunci: perkembangan teknologi komunikasi, google play, kebutuhan informasi. 


\section{PENDAHULUAN}

Pada dasarnya sebuah teknologi diciptakan untuk membuat pekerjaan manusia lebih mudah, cepat dan efisien. Teknologi yang semakin berkembang ini membuat semua aspek kehidupan tidak dapat terlepas dari penggunaan teknologi, baik secara langsung maupun tidak langsung. Seiring dengan perkembangan era globalisasi tuntutan kebutuhan pertukaran informasi dalam berkomunikasi menjadi sangat mutlak untuk dilakukan (suryanto 2015)

Hassan Fuad (1999) mengemukan teknologi komunikasi cenderung memungkinkan terjadinya transformasi berskala luas dalam kehidupan manusia.Tranformasi tersebut telah memunculkan perubahan dalam berbagai pola hubungan antar manusia, yang pada hakikatnya adalah interaksi antar pribadi.Pertemuan tatap muka secara berhadapan dapat dilaksanakan dalam jarak jauh yang sangat jauh melalui tahap citra.Teknologi komunikasi sekarang ini semakin banyak yang dikembangkan, seperti contohnya telepon selular.

Penggunaan telepon selular menjadi kebutuhan yang sangat penting bagi kehidupan saat ini yang memerlukan kebutuhan informasi yang tinggi. Fasilitasfasilitas yang terdapat didalamnya pun tidak hanya terbatas pada fungsi telepon dan SMS (short messages service) saja. Namun lebih kepada punaaneng aplikasi digital, music, games, mengolah data, internet searching, video call dan lainya, yang sering kita sebut dengan ponsel pintar atau Smartphone.

Saat ini pengguna Smartphone di Indonesia terus meningkat. Sebuah lembaga riset menyebutkan bahwa Indonesia berada di peringkat kelima daftar pengguna smartphone terbesar di dunia. Data tersebut dilansir oleh Horace $H$. Dediu melalui blognya, asymco.com. Pada laman detik.com tertulis jika populasi Android telah mrncapai lebih dari 1 miliar, sedangkan iOS mencapai 700 juta.

Temuan Locket senada dengan hasil studi serupa yang dilaporkan oleh $A B C$ News pada akhir Mei 2013. Laporan Internet Trends Kleiner Perkins Caufield \& Byers's tersebut bahkan menyebutkan angka yang tinggi, yaitu pengguna rata-rata mengecek ponselnya 150 kali dalam sehari. Jika diakumulasi, dalam satu minggu rata-rata orang bisa menggunakan Smartphone-nya lebih dari 1.050 kali (kompas.com).

Ponselcerdas (bahasa Inggris: Smartphone) itu sendiri adalah telepon genggam yang mempunyai kemampuan dengan pengunaan dan fungsi yang menyerupai komputer. Belum ada standar pabrik yang menentukan arti ponsel cerdas. Bagi beberapa orang, ponsel cerdas merupakan telepon yang bekerjamenggunakan seluruh perangkat lunak sistem operasi yang menyediakan hubungan standar dan mendasar bagi pengembang aplikasi (Wikipedia.com).

Bagi yang lainnya, ponsel cerdas hanyalah merupakan sebuah telepon yang menyajikan fitur canggih seperti surel (surat), internet dan kemampuan membaca buku elektronik ( $e$ book) atau terdapat papan ketik (baik sebagaimana jadi maupun dihubung keluar) dan penyambung VGA. Dengan kata lain, ponsel cerdas merupakan komputer kecil yang mempunyai kemampuan sebuah telepon. Sebuah ponsel cerdas juga memerlukan sebuah perangkat canggih untuk menunjang kinerja sebuah Smartphone, salah satunya sistem android. Android adalah sistem

operasi berbasis Linux yang dirancang untuk perangkat seluler layar sentuh seperti telepon pintar dan komputer tablet. Android memiliki sejumlah besar komunitas pengembang aplikasi (apps) yang memperluas fungsionalitas perangkat, umumnya ditulis dalam versi kustomisasi bahasa pemrograman Java.

Pada bulan Oktober 2012, ada sekitar 700.000 aplikasi yang tersedia untuk Android, dan sekitar 25 juta aplikasi telah diunduh dari Google Play, toko aplikasi utama Android. Sebuah survey pada bulan April-Mei 2013 menemukan bahwa Android adalah platform paling populer bagi para pengembang, digunakan oleh $71 \%$ pengembang aplikasi seluler. 
Pada bulan September 2012, ada lebih dari 675.000 aplikasi yang tersedia untuk Android, dan perkiraan jumlah aplikasi yang diunduh dari Play Store adalah 25 miliar. Jumlah ini diperkirana akan semakin bertambah seiring dengan banyknya aplikasi-aplikai yang tersedia juga bertambahnya para pengguna ponsel pintar khususunya berbasi android (Wikipedia.com).

Saat ini banyak Mahasiswa yang beralih menggunakan Smartphoneandroid dan aplikasi Google Playuntuk dijadikan sebagai media dalam mengakses informasi secara mudah dan cepat. Hal tersebut juga terjadi dikalangan mahasiswa yang dalam pengamatan peneliti adalah generasi yang peka terhadap teknologi -teknologi baru dan inovasi baru. Remaja dikenal sangat peka dengan hal -hal yang baru dan tidak menutup kemungkinan salah satunya adalah Smartphone.

Abdul kadir (2002) mendefinisikan informasi ialah sebagai data yang telah diperoses sedemikian rupa sehingga dapat meningkatkan pengetahuan seseorang yang menggunakan data tersebut.

Informasi adalah suatu keadaan dimana seseorang menyadari bahwa dirinya memiliki pengetahuan yang kurang mecukupi sehingga membutuhkan informasi untuk memenuhi kekurangn yang dimilikinya.Seperti yang dikemukakan oleh Nicolas (2000) "kebutuhan informasi timbul ketika sesorang menyadari adanya jurang atau jarak antara pengetahuan yang sudah dimiliki oleh dirinya dengan dengan oermahsalahan yang dihadapinya".
Dengan adanya kesadaran terhadap kebutuhan pemenuhan informasi maka dengan sendirinya menimbulkan permintaan informasi oleh pengguna informasi tersebut.Begitu pula dengan yang terjadi di kalangan mahasiwa, mereka sebagai pengguna layanan aplikasi digital Google Play menuntut ketersedian informasi untuk pemenuhan kebutuhan informasinaya.

Ada banyak jenis kebutuhan informasi, seperti Katz yang dikutip oleh Yusup (2009), antara lain adalah :

a. Kebutuhan kognitif. b. Kebutuhan afektif. c. Kebutuhan integrasi personal (personal integrative needs). Ini dikaitkan dengan penguatan kredibilitas, kepercayaan, stabilitas, dan status individu. Kebutuhankebutuhan ini berasal dari hasrat seseorang untuk mencari harga diri. d. Kebutuhan integrasi sosial (social integrative needs). e. Kebutuhan berkhayal (escapist needs).

Dalam Penelitian ini peneliti mengangkat tentang pemanfaatan layanan aplikasi Google Play dalam pemenuhan kebutuhan informasi pada responden Bogor. Karena mahasiswa ilmusosial, politik dan komunikasi secara khusus mempelajari tentang berbagai macam media informasi baik pemahaman secara teori dan praktek.

Adapun mahasiswa ilmusosial, politik dan komunikasi juga mempelajari aspek -aspek komunikasi dalam penyampaian informasi melalui media. Atas dasar itulah yang membuat peneliti berasumsi awal bahwa pada mahasiswa ilmu social, politik dan komunikasi merupakan tempat yang cocok untuk meneliti hal ini. Karena secara teori dan praktek memungkinkan lebih paham tentang masalah yang akan dikaji. 
Gambar 1. Penggunaan Layanan Aplikasi Digital Google Play Dengan Pemenuhan Kebutuhan Informasi

\begin{tabular}{|c|}
\multicolumn{1}{c|}{ Variabel X } \\
\hline $\begin{array}{c}\text { Pengggunaan layanan ap;ikasi digital } \\
\text { gooogle play }\end{array}$ \\
\hline X.1 Pengguna Layanan \\
X.1.1 Frekluensi \\
X.1.1.2 Durasi \\
X.1.1.3 Aktifitas \\
X.2 Aplikasi Google Play \\
X.2.1 Kelengkapan fungsi/ fitur \\
X.2.2Kehandalan \\
X.2.3 Kemudahan penggunaan \\
X.2.4 Inovasi \\
X.2.5 Keamanan \\
X.2.6 Kualitas \\
X.2.7 Biaya \\
\hline
\end{tabular}

\section{MATERI DAN METODE}

Penelitian ini menggunakan metode deskriptip asosiatif dengan pendekatan kuantitatif.Penelitian dilakukan di Fisip Universitas Djuanda Kota Bogor dengan populasi penelitian adalah responden. Penarikan sampel dilakukan dengan menggunakan teknik simple random sampling.Penentuan sampel menggunakan rumus Taro Yamane dengan tingkat kepercayaan (sampling error) 10\%, jumlah sampel penelitian sebanyak 81mahasiswa.Data penelitian dikumpulkan berdasarkan data primer dan data sekunder. Pengumpulan data primer dilakukan melaluipenyebaran kuesioner, wawancara dan observasi. Sedangkan data sekunder dikumpulkan dari artikel, website, dan dokumen yang relevan.Data penelitian dianalisis dengan prosedur statistikmenggunakan Skala Likert untuk melakukan pengukuran terhadap data interval. Skala pengukuran ini bertujuan untuk Untuk menentukan kriteria penilaian maka dicari interval masing-masing skor jawaban, yakni interval dari satu kriteria dengan kriteria yang lainnya diperoleh angka sebesar 0,8.Data interval tersebut kemudian akan dianalisis menggunakan rumus statistik koefisien korelasi tata jenjang Rank Spearman (Sugiono2011).

\section{HASIL DAN PEMBAHASAN}

Karakteristik responden berdasarkan jenis kelamin, jurusan, usia, program keahlian, intensitas penggunaan dan pengunduhan yang dilakukan di layanan aplikasi digital google play,Sebagaimana Tabel 1 berikut ini. 
Tabel 1

Jumlah dan Presentase responden Bogor Berdasarkan Karakteristik Responden

\begin{tabular}{|c|c|c|c|}
\hline Karakteristik Responden & & Jumlah & Presentase \\
\hline & Pria & 38 & $47 \%$ \\
\hline Jenis Kelamin & Wanita & 43 & $53 \%$ \\
\hline \multicolumn{2}{|l|}{ Total } & 81 & 1005 \\
\hline \multirow{2}{*}{\multicolumn{4}{|c|}{ Administrasi Negara }} \\
\hline & & & \\
\hline & Ilmu Komunikasi & 42 & $52 \%$ \\
\hline \multirow[t]{3}{*}{ Total } & & 81 & $100 \%$ \\
\hline & 18-29 Tahun & 80 & $99 \%$ \\
\hline & & & \\
\hline & $>40$ tahun & 1 & $1 \%$ \\
\hline \multicolumn{2}{|l|}{ Total } & 81 & $100 \%$ \\
\hline & 1-2 kali per minggu & 57 & $70 \%$ \\
\hline \multirow[t]{2}{*}{ Intensitas Penggunaan layanan aplikasi play store } & 3-4 kali per minggu & 7 & $9 \%$ \\
\hline & $>4$ kali perminggu & 17 & $21 \%$ \\
\hline \multicolumn{2}{|l|}{ Total } & 81 & $100 \%$ \\
\hline \multirow{3}{*}{ Intensitas pengunduhan/pembelian di layanan aplikai play store } & 1-2 kali per minggu & 68 & $84 \%$ \\
\hline & 3-4 kali per minggu & 10 & $12 \%$ \\
\hline & $>4$ kali perminggu & 3 & $4 \%$ \\
\hline \multicolumn{2}{|l|}{ Total } & 81 & $100 \%$ \\
\hline
\end{tabular}

Hasil Penelitian :2015

Berdasarkan Tabel 1 jenis kelamin responden sebagian antara laki-laki dan wanita cukup berimbang, dengan rentang usia sebagian besar berusia 20-22 tahun. Sedangkan program keahlian sebagian antara mahasiswa ilmu komunikasi dan Administrasi juga berimbang. Penggunaan layanan aplikasi google play di smartphone android mereka sangat baik, terbukti semua pengguna android pasti mengggunakan layanan tersebut. Penggunaan layanan tersebut cukup aktif dilakukan oleh mahasiswa terbukti dengan rata-rata penggunaan seminggu satu sampai dua kali dan pengunduhan dilakukan satu sampai dua kali dalam satu minggu.

\section{Penggunaan layanan aplikasi google play oleh responden}

Berikut data primer yang terkumpul dari responden mengenai pendapat tentang penggunaan google play dapat dilihat pada tabel Deskripsi data yang digunakan dalam metode distribusi frekuensi (variebel penelitian).Dimensi pertama kelengkapan fungsi dan fitur, dengan indikator: (1)responden menganggap bahwa pada layanan konten digital google play cukup lengkap untuk mendukung pemenuhan kebutuhan informasi mahasiwa karena dalam aplikasi tersebut banyak sekali aplikasi dan layanan konten digital yang tersedia untuk digunakan dalam memenuhi kebutuahan informasi. (2)responden menganggap bahwa aplikasi dan konten digital pada aplikasi google play mempermudah mahasiswa mendapatkan informasi mahasiwa karena dalam aplikasi 
tersebut memudahkan mahasiswa dalam mencari dan memilih aplikasi dan konten digital mana yang akan diunduh untuk digunakan dalam mengakses informasi. (3)responden menganggap aplikasi dan konten digital pada aplikasi google play mempermudah tugas mahasiswa karena dalam aplikasi tersebut banayak sekali aplikasi dan konten digital yang berfungsi untuk membantu mahasiswa dalam memudahkan dalam menegerjakan tugas. (4) responden menganggap aplikasi dan konten digital pada aplikasi google play membantu mahasiswa mengerjakan tugas lebih baik karena dalam aplikasi tersebut banayak sekali aplikasi dan konten digital yang berfungsi untuk membantu mahasiswa dalam memudahkan dalam menegerjakan tugas.dimensi kedua kehandalan, dengan indikator; (5) responden menganggap ragu-ragu bahwa penggunann aplikasi google play jarang mengalami gangguan (hang) saat di gunakan. Berdasarkan wawancara kepada mahasiswa bahwa gangguan pada layanan aplikai google play jarang terjadi, namun tidak semua penggunaan google play oleh mahasiswa tidak mengalami gangguan, gangguan tesebut biasanya karena beberapa faktor seperti gangguan pada google play itu sendiri, smartphone, jaringan dan lainya yang mendukung penggunaan layanan aplikasi digital tersebut. Dimensi ketiga kemudahan, dengan indikator; (6)responden menganggap google play mudah digunakan mahasiswa (7) responden menganggap google play mudah dipelajari mahasiswa. (8)responden menganggap bahwa mengakses aplikasi dan konten digital tidak perlu proses yang rumit karena pengguna hanya diharuskan memiliki email google untuk mendaftarkan agar dapat membuka dan mengoprasikan google play di smartphone mereka. (9)responden menganggap bahwa gaya penulisan dan ejaan bahasa dalam layanan aplikasi google play mudah untuk dimengerti sehingga penggunaannya menjadi mudah.Dimensi ke empat inovasi, dengan indikator; (10) responden menganggap bahwa Penggunaan aplikasi goggle play merupakan terobosan baru dibandingkan aplikasi lain, karena mereka berpendapat penggunaan google play semakin memudahkan mereka karena aplikasi tersebut menyediakan banayak sekali aplikasi dan layanan konten digital untuk di unduh. (11)responden menganggap bahwa Penggunaan aplikasi goggle play merupakan wujud dalam mengikuti perkembangan teknologi komunikasi karena perkembangan teknologi komunikasi semakin memudahkan penggunaannya untuk mendapatkan informasi lebih cepat dan efisien. Dimensi kelima keamanan, dengan indikator;(12) responden menganggap bahwa Aplikasi goggle play memiliki sistem keamanan yang membuat setiap orang tidak bisa mengakses milik kita karena penggunaan google play dalam smartphone kita diwaibkan untuk mendaftarkan pengguna menggunakan email google milik kita. (13) responden menganggap bahwa penggunaan google play tidak terlalu memberikan ancaman virus kepada smartphone, namun ada saja mahasiswa berpendapat penggunaan layanan konten digital google play mengundang mengancam virus pada smartphone. Ini dapat terjadi karena penggunaan google play menggunakan akses internet sehingga bisa saja virus masuk den menganggu kinerja smartphone. Indikator ke enam kualitas, dengan indikator; (14) responden menganggap bahwa bahwa layot pada google play terlihat rapi, proposional dan lucu sehingga membuat pemakai menjadi nyaman untuk menggunakannya. (15) responden menganggap bahwa Warna tampilan aplikasi goggle play terlihat halus, propoianal dan tidak terlihat mencolok sehingga membuat pemakai menjadi nyaman untuk menggunakan layanan aplikasi tersebut. Dimensi ke tujuh biaya, dengan indikator: (16) responden Fisip Unida menganggap bahwa pembelian dan pengunduhan aplikasi dan konten digital yang tersedia dalam play store terjangkau oleh keuangan mahasiswa karena dalam layanan aplikai digital google play banyak sekali aplikasi dan konten digital yang dapat di unduh secara gratis. 
Tabel 2 Penggunaan Layanan Aplikasi digital Google Play oleh Responden

\begin{tabular}{|c|c|c|c|c|c|c|c|c|c|}
\hline \multirow[t]{2}{*}{ NO } & \multirow[t]{2}{*}{ Indikator } & \multicolumn{5}{|c|}{ Frekuensi } & \multirow[t]{2}{*}{$\underline{\mathrm{F}(\mathrm{x})}$} & \multirow{2}{*}{$\begin{array}{l}\left.\sum \mathrm{f}(\mathrm{x})\right) / \\
\mathrm{N}\end{array}$} & \multirow{2}{*}{$\begin{array}{c}\text { Krite } \\
\text { ria }\end{array}$} \\
\hline & & SS & $\mathrm{S}$ & $\mathrm{R}$ & TS & STS & & & \\
\hline \multicolumn{10}{|c|}{ kelengkapan fungsi dan fitur } \\
\hline 1 & $\begin{array}{l}\text { Aplikasi dan konten digital pada google play cukup lengkap untuk } \\
\text { mendukung pemenuhan kebutuhan informasi. }\end{array}$ & 17 & 62 & 2 & 0 & 0 & 333 & 4,11 & Baik \\
\hline 2 & $\begin{array}{l}\text { Aplikasi dan konten digital pada aplikasi google play mempermudah } \\
\text { mendapatkan informasi edukasi. }\end{array}$ & 22 & 53 & 6 & 0 & 0 & 340 & 4,20 & baik \\
\hline 3 & $\begin{array}{l}\text { Aplikasi dan konten digital yang tersedia dalam google play dapat } \\
\text { mempermudah tugas mahasiswa }\end{array}$ & 12 & 34 & 28 & 7 & 0 & 328 & 4,04 & baik \\
\hline 4 & $\begin{array}{l}\text { Aplikasi dan konten digital dalam google play membantu mahasiswa } \\
\text { mengerjakan tugas lebih baik }\end{array}$ & 9 & 35 & 27 & 7 & 3 & 283 & 3,50 & Baik \\
\hline \multicolumn{10}{|c|}{ Kehandalan } \\
\hline 5 & $\begin{array}{l}\text { Aplikasi google play jarang mengalami gangguan (hang) ketika digunakan } \\
\text { mahasiswa }\end{array}$ & 6 & 28 & 30 & 17 & 0 & 266 & 3,29 & $\begin{array}{l}\text { cuku } \\
\text { p } \\
\text { baik }\end{array}$ \\
\hline \multicolumn{10}{|c|}{ kemudahan penggunaan } \\
\hline 6 & Aplikasi goggle play mudah digunakan mahasiswa & 25 & 48 & 7 & 0 & 1 & 399 & 4,19 & Baik \\
\hline 7 & Aplikasi google play mudah dipelajari. & 17 & 51 & 3 & 10 & 0 & 318 & 3,92 & Baik \\
\hline 8 & Untuk dapat mengakses google play tidak diperlukan proses yang rumit & 17 & 51 & 3 & 10 & 0 & 318 & 3,92 & Baik \\
\hline 9 & $\begin{array}{l}\text { Gaya penulisan dan ejaan bahasa di layanan aplikasi digital goggle play } \\
\text { bersifat umum dan sesuai ejaan bahasa Indonesia yang baik (EYD) }\end{array}$ & 11 & 57 & 10 & 3 & 0 & 319 & 3,93 & Baik \\
\hline \multicolumn{10}{|c|}{ Inovasi } \\
\hline 10 & $\begin{array}{l}\text { Penggunaan aplikasi goggle play merupakan terobosan baru dibandingkan } \\
\text { aplikasi lain }\end{array}$ & 9 & 46 & 25 & 1 & 0 & 306 & 3,78 & Baik \\
\hline 11 & $\begin{array}{l}\text { Penggunaan aplikasi google play merupakan wujud dalam mengikuti } \\
\text { perkembangan teknologi komunikasi }\end{array}$ & 31 & 46 & 4 & 0 & 0 & 346 & 4,28 & $\begin{array}{l}\text { Sang } \\
\text { at } \\
\text { Baik }\end{array}$ \\
\hline
\end{tabular}

\section{Keamanan}

12 Aplikasi goggle play memiliki sistem keamanan yang membuat setiap

$\begin{array}{llllllll}12 & 34 & 30 & 3 & 2 & 294 & 3,62 & \text { Baik }\end{array}$ orang tidak bisa mengakses milik kita

13 Aplikasi goggle play aman dari ancaman virusterhadap smartphon

Kualitas

\begin{tabular}{|c|c|c|c|c|c|c|c|c|c|}
\hline 14 & $\begin{array}{l}\text { Penataan atau layout dan tampilan aplikasi google play terlihat dan rapih } \\
\text { dan proposional }\end{array}$ & 16 & 54 & 8 & 3 & 0 & 326 & 4,02 & Baik \\
\hline 15 & $\begin{array}{l}\text { Warna tampilan aplikasi goggle play terlihat halus, propoianal dan tidak } \\
\text { terlihat mencolok }\end{array}$ & 10 & 54 & 13 & 4 & 0 & 313 & 3,87 & Baik \\
\hline
\end{tabular}

Biaya

16 Pembelian/ pengunduhan aplikasi dan konten digital yang tersedia dalam $\quad \begin{array}{lllllll}6 & 40 & 21 & 12 & 2 & 279 & 3,44\end{array} \quad$ Baik play store terjangkau oleh keuangan mahasiswa 


\begin{tabular}{lcc}
\hline Jumlah Angka Penafsiran & 62,40 & Baik \\
Rata-rata Angka Penafsiran & 3,97 & \\
\hline
\end{tabular}

Sumber: Hasil Penelitian 2015

Berdasarkan hasil penelitian, sebagian besar responden setuju penggunaan layanan aplikasi digital google play dapat memberikan maanfaat yang baik terutama dalam memberi informasi, ini dilihat dari kelengkapan layanan konten digital dan aplikasi yang ditawarkan didalamnya, pengunduhan apliaksi dan konten digitalpun tidak terlalu sulit dilakukan oleh mahasiswa.penggunaannya dikalangan mahasiswa juga dinilai mudah dan tidak memerlukan proses yang rumit. Perkembangan teknologi komunikasi pun telah dirasakan dan dimanfaatkan dengan baik oleh responden, ini dapat dilihat dari dimensi tentang inovasi yang oleh sebagian besar mahasiswa setuju dengan hal tersebut, sehingga kalangan mahasisa dinilai sangat terbuka dengan perkembangan teknologi komunikasi untuk dimanfaatkan ebagai media pemenuhan kebutuhan informasi.

\section{Kebutuhan Informasi}

Berikut data primer yang terkumpul dari tanggapan mahaswa mengenai kebutuahn informasi, dimensi pertama kebutuhan afektif, dengan indikator; (1)responden menganggap bahwaPenggunaan aplikasi google play dapat memberikan informasi edukasi karena banyak aplikasi dan konten digital yang tersedia berguna untuk melaukan komunikasi dan mencari informasi yang bersifat edukasi seperti mdia social, google play book, konten digital seperti detik.com dan lain-lain. (2) responden menganggap bahwa Penggunaan aplikasi google play dapat memberikan informasi edukasi karena layanan aplikasi dalam google play memberikan kemudahan akses untuk dapat mencari informasiinformasi sehingga pengetahuan dan pemahaman akan bertambah karena terpenuhunya informasi. Dimensi kedua kebutuhan kognitif, dengan indikator;(3)responden menganggap bahwa layanan aplikasi goggle play dapat memberikan hiburan bagi pengggunannya karena ketika sedang bosan dan jenuh, seringkali mahasiswa menggunakan layanan konten digital gooogle play untuk mencari hiburan-hiburn seperti mengunduh game.Dimensi ketiga kebutuhan pelepasan ketegangan, pelarian dan peralihan, dengan indikator; (4)Fisip Unida menganggap bahwa Penggunaan smartphone dan aplikasi digital google play dilakukan untuk mengisi waktu luang, kepenatan dan menghilangkan stress karena konten digital google play salah satunya untuk mengisi waktu luang dan kepanatan karena banyak sekali hiburanhiburan yang didapatkan di google play seperti game, book, film dan konten digital lainya yang bersifat hiburan.dimensi ke empat kebutuhan integrative personal, dengan indikator; (5)responden menganggap bahwa Pengguna layanan aplikasi goggle play bisa merubah status dirinya dari penguna bisa menjadi penggemar. Dimensi kelima kebutuhan integrative social, dengan indikator; (6) responden menganggap bahwa Penggunaan layanan aplikasi digital goggle play dapat menjadi bahan pembicaraan untuk dapat berinteraksi dengan orang lain. 
Tabel 3 Tanggapan Responden Tentang Motivasi Belajar Siswa Di SMK Wikrama Kota Bogor

\begin{tabular}{|c|c|c|c|c|c|c|c|c|c|}
\hline \multirow[t]{3}{*}{ NO } & \multirow[t]{2}{*}{ Indikator } & \multicolumn{5}{|c|}{ Frekuensi (f) } & \multirow[t]{3}{*}{$\mathrm{F}(\mathrm{x})$} & \multirow[t]{3}{*}{$\sum \mathrm{f}(\mathrm{x}) \mathrm{J} / \mathrm{N}$} & \multirow[t]{3}{*}{ Kriteria } \\
\hline & & SS & $\mathrm{S}$ & $\mathrm{R}$ & TS & STS & & & \\
\hline & \multicolumn{6}{|l|}{ Kebutuhan Afektif } & & & \\
\hline 17 & $\begin{array}{l}\text { Aplikasi google play dapat memberikan informasi } \\
\text { edukasi. }\end{array}$ & 24 & 46 & 7 & 4 & 0 & 333 & 4,11 & Baik \\
\hline \multirow[t]{2}{*}{18} & $\begin{array}{l}\text { Aplikasi goggle play dapat memberikan } \\
\text { pengetahuan dan pemahaman bagi penggunannya. }\end{array}$ & 22 & 49 & 8 & 2 & 0 & 334 & 4,12 & Baik \\
\hline & \multicolumn{9}{|l|}{ Kebutuhan Pemahaman (Kognitif) } \\
\hline \multirow[t]{2}{*}{19} & $\begin{array}{l}\text { Aplikasi google play memberikan hiburan bagi } \\
\text { penggunannya }\end{array}$ & 33 & 47 & 0 & 1 & 0 & 335 & 4,39 & $\begin{array}{l}\text { Sangat } \\
\text { Baik }\end{array}$ \\
\hline & \multicolumn{9}{|c|}{ Kebutuhan pelepasan ketegangan, pelarian dan peralihan } \\
\hline \multirow[t]{2}{*}{20} & $\begin{array}{l}\text { Penggunaan aplikasi digital google play dilakukan } \\
\text { untuk mengisi waktu luang, kepenatan dan } \\
\text { menghilangkan stres }\end{array}$ & 18 & 54 & 6 & 3 & 0 & 330 & 4,08 & Baik \\
\hline & \multicolumn{9}{|l|}{ Kebutuhan integrative personal } \\
\hline 21 & $\begin{array}{l}\text { Pengguna layanan aplikasi goggle play bisa } \\
\text { merubah status dirinya dari penguna bisa menjadi } \\
\text { penggemar }\end{array}$ & 9 & 29 & 37 & 6 & 0 & 284 & 3,50 & Baik \\
\hline \multirow[t]{3}{*}{22} & $\begin{array}{l}\text { Penggunaan layanan aplikasi digital goggle play } \\
\text { dapat menjadi bahan pembicaraan untuk dapat } \\
\text { berinteraksi dengan orang lain. }\end{array}$ & 7 & 48 & 21 & 2 & 0 & 300 & 3,70 & Baik \\
\hline & Jumlah Angka Penafsiran & & & & & & & 23,09 & Baik \\
\hline & Rata-rata Angka Penafsiran & & & & & & & 3,95 & \\
\hline
\end{tabular}

Berdasarkan hasil penelitian sebagian besar menyatakan setuju aplikasi google play memenuhi kebutuhan informasi. Kebutuhan afektif yang terdiri dari kebutuhan pengetahuan mahasiswa tentang informasi edukasi terpenuhi dengan baik, responden juga merasa penggunaan google play juga telah memeberikan hiburan, mengisi waktu luang, kepenatan. Penggunaan layanan aplikasi digital google yang dilakukan secara intens dan terus menerus juga bisa merubah pengguna yang dalam hal ini adalah mahasiswa
Fisip Universitas Djuanda menjadi penggemar, hal ini dapat terjadi karena kebutuhan akan layanan aplikasi dan konten digital itu sendiri di google play.layanan aplikasi google

\section{Uji Hipotesis}

Uji hipotesis ini untuk mengetahui hubungan antara penggunaan layanan aplikasi digital google play dengan pemenuhan kebutuhan informasi secara menyeluruh berdasarkan uji korelasi rank spearman, yang dapat dilihat pada Tabel 5. 
Tabel 5 Hubungan pengunaan google play dengan pemenuhan kebutuhan informasi

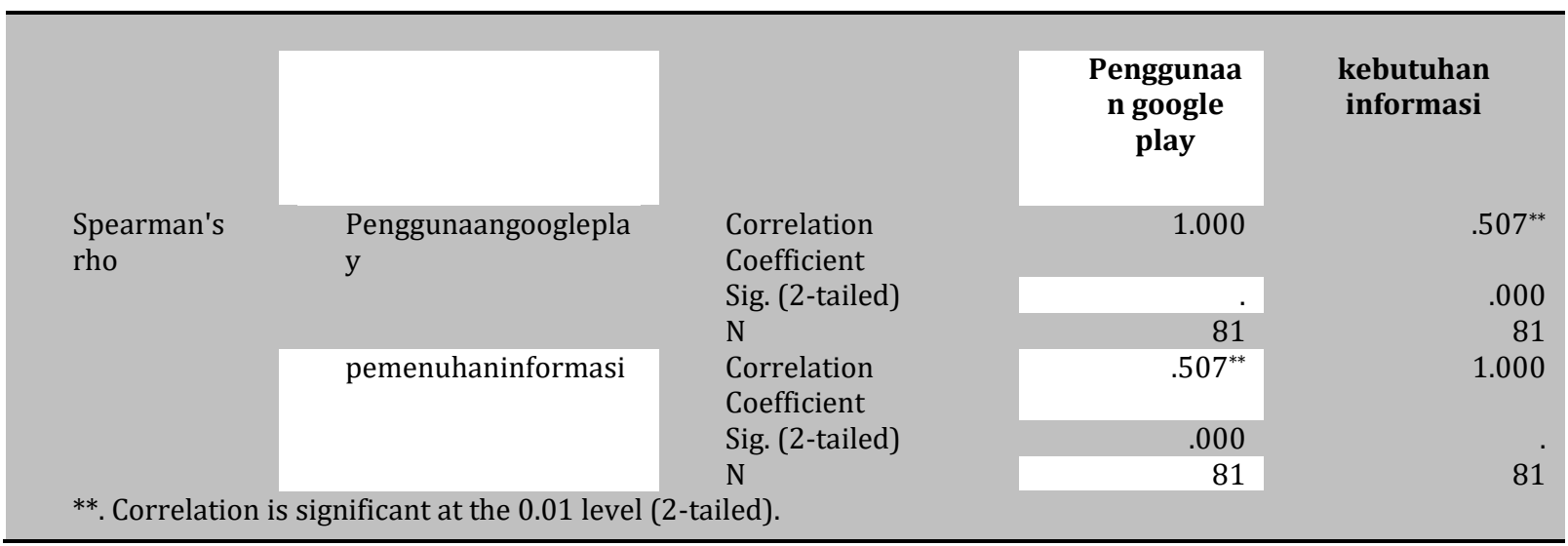

Berdasarkan tabel diatas dapat disimpulkan bahwa variabel penggunaan google play berkorelasi positif dengan pemenuhan kebutuhan informasi artinya semakin baik penggunaan layanan aplikasi digitak goggle play maka semakin terpenuhi kebutuhan mahyasiswa akan informasi, demikian pula sebaliknya. Besaran koefisien korelasi adalah 0,507 dan terdapat signifikansi 0,000 dengan taraf kesalahan 0,05 maka dapat dikatakan tidak signifikan. Berdasarkan kriteria Interpretasi Koefisien Korelasi tabel 3.4, besaran koefisien 0,507 mengindikasikan tingkat hubungan yang cukup baik, yang berarti bahwa kedua variabel tersebut memang secara nyata berkorelasi.

\section{Uji Signifikansi}

Untuk menentukan diterima atau ditolaknya hipotesis maka dilakukan pengujian koefisien korelasi dengan rumus uji t :

$t=r s \sqrt{\frac{N-2}{1-r s^{2}}} t=0,507 \sqrt{\frac{79}{0,743}} t=10,3$

11

Ketentuan Pengujian: bila $t_{\text {hitung }}$ lebih besar dari $t_{\text {tabel }}$ maka koefisien korelasi rank spearman yang ditemukan signifikan (nyata) atau dapat digeneralisasikan.

Dari hasil perhitungan diperoleh nilai $t_{\text {hitung }}$ hasil penelitian sebesar 10,311 kemudian nilai $t_{\text {hitung }}$ dibandingkan dengan $t_{\text {tabel }}$ distribusi $t$ dengan taraf signifikan $5 \%$ maka diperoleh nilai $t_{\text {tabel }}$ adalah 0,677. Hal tersebut menunjukan bahwa ternyata $T_{\text {hitung }}>\mathrm{T}_{\text {tabel. }}$. Dengan demikian maka dapat disimpulkan bahwa koefisien korelasi rank spearman signifikan, sehingga Ho ditolak dan $\mathrm{Ha}$ diterima.

Jadi kesimpulannya adalah, apabila penggunaan layanan aplikasi digital google play di hubungkan dengan pemenuhunah informasi maka hasilnya $=0,507$ pada taraf $5 \%$ dengan kepercayaan 95\%, artinyaterdapat berhubungan antara penggunaan layanan aplikasi google play dengan pemenuhan kebutuhan informasi. Hal senada hasil penelitian Prayogi (2015) bahwa terdapat hubungan antara penggunaan teknologi komunikasi dengan minat belajar seseorang. Oleh karena itu aplikasi dari google play store perlu menyediakan lebih banyak aplikasi dan layanan konten digital sehingga kebutuhan pemenuhan informasi lebih tinggi.

\section{KESIMPULAN DAN SARAN}

\section{Kesimpulan}

(1) Penggunaan layanan aplikasi digital google play oleh responden berada dalam kategori baik. Indikator tentang layanan aplikasi google play merupakan wujud dari mengikuti perkembangan teknologi komunikasi menjadi indikator dengan nilai tertinggi. Dengan demikian dapat disimpulkan bahwa responden 
sangat mengikuti perkembangan teknologi komunikasi dan memanfaatkanya dengan baik.

(2) faktor yang memepengaruhi pengunaan layanan aplikasi digital google play adalah kebutuhan afektif yaitu kebutuhan akan informasi, pengetahuan dan pemahaman. Kebutuhan kognitif yaitu kebutuhan responden akan hiburan. Kebutuhan pelepasan ketegangan, pelarian dan peralihan yaitu pengunaan layanan apliaksi goggle play dilakukan untuk mengisi waktu luang, kepenatan dan menghilangkan stress. Kebutuhan integrative personal yaitu penggunaan google play dapat merubah si pengguna menjadi penggemar aplikasi tersebut dan kebutuhan integrative social yaitu pengguna layanan apliaksi google play dapat menjadikan bahan perbincangan untuk berinteraksi dengan orang lain. Semua dimensi dikategorekan baik, namun pada dimensi kepuasan kebutuhan pemahamam (kognitif) dengan indikator penggunaan google play memeberikan hiburan berada pada kategori sangat baik, sehingga dapat disimpulkan faktor tertinggi yang dapat mempengaruhi penggunaan google play pada responden adalah kebutuhan hiburan.

(3) Penggunaan google play berkorelasi positif dengan pemenuhan kebutuhan informasi artinya semakin baik penggunaan layanan aplikasi digital goggle play maka semakin terpenuhi kebutuhan mahasiswa akan informasi, demikian pula sebaliknya. Besaran koefisien korelasi adalah 0,507 dan terdapat signifikansi 0,000 dengan taraf kesalahan 0,05 maka dapat dikatakan tidak signifikan. Berdasarkan kriteria Interpretasi Koefisien Korelasi tabel 35, besaran koefisien 0,507 mengindikasikan tingkat hubungan yang cukup baik, yang berarti bahwa kedua variabel tersebut memang secara nyata berkorelasi.

\section{Implikasi}

Implikasi dari penelitian ini adalah layanan aplikasi google play store perlu menambah layanan konten digital dan aplikasi yang bersifat edukatif. Selain itu perlu diyakinkan pengguna untuk keamanan penggunaan aplikasi google play store dari ancaman virus terhadap smartphone.

\section{DAFTAR PUSTAKA}

Efendi, Yusuf. (2009). Merancang Jaringan Komunikasi VoIP Sederhana dengan Server VoIP Trixbox yang dilengkapi VQManager dan Open VPN. Semarang

Fuad H. Teknologi dan dampak kebudayaan: Tantangan Dalam Laju Teknologi.Orasi Ilmiah Dies Natalis Institut Teknologi Sepuluh november ke-39. Surabaya. Diunduh 12 Mei 2016, dalam zkarnain.tripod.com/its-2.htm.

Nicolas, David. (2000). Assessing informations need: tools, techniques and concept for the internet Age. Ed.2.london: Aslib

\begin{tabular}{lrr} 
Prayogi R, Suryatna & U & dan \\
Kusumadinata & AA. & 2015. \\
Hubungan & \multicolumn{3}{c}{ Komunikasi } \\
Pembelajaran Sistem & E-Learning \\
dengan Motivasi Belajar. Jurnal \\
Penelitian Komunikasi: Vol. 1 \\
Nomor 2; Hal. 99-113.
\end{tabular}

Sugiyono. 2011. Metode Penelitian Administrasi. Bandung: Alfabeta.

Suryanto. 2015. Pengantar Ilmu Komunikasi. Bandung; CV Pustaka setia. 
